\title{
Considerations regarding the risk of integrity - Romanian developments within the European framework
}

\author{
Mihai Mieilă ${ }^{1}$, Georgiana Vlad (Vasile) $)^{1, *}$, Alexandra Sima (Niţoi) ${ }^{1}$, Anda-Ileana Necula ${ }^{1}$, \\ Mirela Roxana Bărbulescu (Niţa) ${ }^{1}$, and Florian Iancu ${ }^{1}$
}

${ }^{1}$ Doctoral School of Economic Sciences and Humanities, „Valahia” University of Târgovişte, Romania.

\begin{abstract}
In the process of risk management process implementation and deployment within the organizations, both public and private, the applicable standards outline the role played the human resources, as the key issue in this respect. Following the standards and the practice in the field, the integrity risks are considered within the framework of a holistic approach. The paper tries to introduce and address the main features of the integrity risks, considering the European approach, based on the quantitative and qualitative measurement through some specific indicators. Besides, the joint-approaches of the developments in the legal framework, and the other international bodies involved in regulation of the field, namely the Organization for Economic Cooperation and Development and the United Nations Convention against Corruption are outlined. In addition, the public perception indicators regarding the integrity are presented through the comparative examination of the local findings amongst the other European countries and averages, pointing out the specific evolutions. The conclusions highlight the favourable changes and some of the actions required as prerequisites for necessary further improvements.
\end{abstract}

Research background: Defined as the abuse of power oriented towards gain of private benefits, the corruption is a phenomenon that affects the economies and the fair distribution of welfare. Although there is a regulatory framework both at national and international levels, measuring of corruption remains a difficult task, as it often relies on public perception.

Purpose of the article: The objectives consist in identification and assessment of integrity risks, besides the implementation of the adequate control tools, in order to ensure their proper monitoring.

Methods: Employing the data from the international surveys and indexes used in measurement of the corruption perception, and considering the applicable legal framework, there are examined both the specific trends in Romania, compared to the general developments in the European Union .

Findings \& Value added: Amid a general improvement trend, there are highlighted some slight backward steps and the necessary actions for future improvements. Considering the weak parts specific to the perception surveys, besides their further usage, results the necessity of fostering the using of special designed indexes, which rely, in addition, on aspects that mainly remain out of public perception.

Keywords: Integrity risks, corruption measurements, European framework on corruption

JEL Classification: $D 63 ; D 73 ; K 42 ; O 15$.

\section{Introduction}

The etymology of the word integrity comes from the adjective "integer", originated in Latin, of whose initial meaning is whole or complete. The transformations of this concept over time have added new significations, which refer to the totality of the qualities of an individual, expressed by honesty and consistency of character [1].

* Corresponding author: g3luk2006@yahoo.com 
The integrity is a concept that resides in actions consistent to own individual and societal values, methods and metrics, as well as related to principles and expectations, which can be verified though the outcomes [2]. Other authors consider that the system of values and principles issued through the social mechanisms is subject to validation over time, traversing an adjustment-and-review process, driven by the intermediary outcomes [3]. This statement does not enter in any contradiction with the objective necessity of a system of principles and values, as the absence of this type of arrangement would invariably promote the inconsistency and confusion.

Implementing of the concept of integrity within the professional relations imply [3-4]:

- being fair, truly and earnest;

- $\quad$ acting honestly and in accordance with the objective reality;

- refraining from using the information that were provided imprudently;

- refraining from using the information containing false or misleading statements, which could mislead consumers;

- refraining from the imprudent using of the acquired information.

The fundamental principles of integrity are the following [5]:

- Honesty is a virtue which resides in support of the truth, is a human quality manifested through integrity, honesty, credibility and honorableness;

- Trust is a sense of security, a sense of dignity, justice and conscience, which serves as a guide in human behavior. The unit of measurement for trust is integrity;

- Justice is a fundamental, moral and legal principle of the society, it is the way in which an individual is treated by other individuals or by the general society;

- The respect is a manifestation of appreciation and esteem for a person, institution, or a community;

- Responsibility is a task of liability; a commitment that relates to the obligations of the individual to the actions taken.

\section{The operational concepts of the integrity risks}

The adequate understanding and management of the integrity risks represent an essential task deployed in order to ensure the effectiveness and the long-term impact of risk mitigation measures. In the area of integrity, the ideal features of these measures are the following:

- clear objectives and demonstrable results;

- trusted, credible and responsible participants;

- inclusive, transparent and responsive processes and governance, leading to informed and balanced decisions;

- the managers play a central role in ensuring and improving the ethics within the organization.

In the field of ethics, the integrity is considered through the personal honesty and the actions consistent to this feature. As in the literature is also pointed out, the integrity is in antithesis with dissimulation, that is, judging through the standards of integrity implies the internal truthfulness as a virtue, and suggests that people holding within antagonist values have to respond to the gap or modify their own beliefs [6].

The sense of the word integrity has evolved from the Latin adjective integer, of whose initial meaning was whole or complete. In this framework, the integrity represents the external reflection of the inner sense that derives from personal qualities as moral probity and consistency of character. Thereby, the integrity of the individuals can be considered through the external reflections of the integrity characteristics, as far as they act in 
accordance with the values, beliefs and principles they claim to have [6]. However, the integrity represents a personal choice, a firm engagement in respect of ethical, moral, artistic, and spiritual principles and values [7].

From this perspective, honest behaviuor is that type of conduct ethically evaluated as fair, and the integrity represents an individual value, which refers to ethical fairness, and which cannot be bounded through the professional and legal honesty. Ensuring the institutional integrity requires the design and implementation of an integrity plan comprising the set of necessary actions identified by the entity's management as remedies for the institutional vulnerabilities and corruption risks.

The adequate measures to be planned and implemented aimed at preventing the integrity risks consist in: the internal and external communication with regards to the activity deployed by the public entity in the filed of fight against corruption. Thereby, the provision of the good practices guides on ethics, internal control, and compliance has to be included within the integrity plans of the legal entities, both public and private [8].

One of the latter developments in the field of integrity risks is represented by the so-called phenomenon of panouflage, that is, the migration of the civil servants from the public service jobs, particularly the high-ranking ones, towards the private sector. The official position documents consider that this type of situation represent a particularly risky, in terms of exposure to corruption [9]. In view of new approaches in the management of public sector, together with extensive work opportunities, there may be observed a shift in the relationships between the public service and private sector, on the one side, and the public perception of these relationships, on the other side. There is an objective need to maintain the public confidence, in particular during periods of change, which increases the importance of design, deployment, and maintaining of the systems in order to address the conflicts of interest, including those arising from the migration of civil servants to business sector.

The most common objectives of a system projected to address the possible risks arising from the migration of public servants to economic sector are to ensure the following [8]:

- the proper usage of the specific information acquired during the deployment of the public service;

- in the exercise of authority a public servant should not be influenced by personal interests, including the expectation for future employment within the economic sector;

- the personal contacts of actual and former civil servants are not used for undue benefits for themselves or for others.

\section{Addressing of the integrity risks - an European approach}

In the framework of the European Union, the member states agreed for a set of regulations on promoting the integrity, both in public and private for or not-for profit organizations. Since the end of the 1990s, the Council of Europe has provided several measures, actions, and tools aimed to address different aspects of corruption, including the Criminal Law Convention on Corruption [10].

The Convention includes articles with regards the corruption in the business sector, distinguishing between the active corruption, provided by the Article 7, on the one hand, and the passive corruption, provided by the Article 8, respectively. In the comparison to the approach considered within the Joint Action and the subsequent framework decision, these articles represent a step forward, that is, their formulation is more comprehensive, as they do not provide any restriction regarding the conduct which may lead to distortions of concurrence [11-12]. However, within the provisions of the Article 18 of the Convention, regarding the corporate responsibility, the passive corruption is not included. 
Although the framework decision and the agreement introduce the expression "legal entity", based on the applicable definitions in the national legislation of each member state, the context is potentially broader in the framework decision, as the latter expressly extends the field of passive corruption offenses and activities within both profit and non-profit entities.

The Criminal Law Convention on Corruption was signed initially by all the member states, but only 19 of them have ratified the agreement. Some member states, according to the specific allowances of the ratification process, have expressed reserves regarding one or more of the aforementioned Articles. The second assessment of the Convention deployed under the aegis of the Council of Europe mechanism (GRECO) (2003-3005), included Article 18 on corporate responsibility within the action sphere of the convention; however, the Articles 7 and 8 on corruption in the private sector did not received a similar attention. In this context, the Council of the European Union promoted and adopted the framework decision 2003/568/JHA on combating corruption in the private sector, according to Title VI of the Treaty on European Union [13]. The objective of this document is to pursue and to guarantee that both active and passive corruption in the economic sector constitute criminal offenses in all Member States, as well the legal entities may be subject of law liability for the corruption offenses, which are punished accordingly by real, dissuasive and proportionate penalties [14].

The framework decision 2003/568/JHA defines and criminalizes as lack-of-integrity behaviours, and consequently as offenses two categories of behaviour, which can be summarized as following:

- to offer, to promise, and to give undue advantages to a person employed by a private a entity as an incentive for performing an action or to refrain from performing an action, thereby in contradiction with normal job obligations;

- to claim or to receive undue benefits or to promise undue benefits in the exercise of normal job obligations in private sector, in order to deploy or to refrain from carrying out of an act, thereby in contradiction with normal job obligations.

The integrity risks in both the public, economic and business sectors have a direct impact on welfare, economic development, and competition. Preventing and mitigating the integrity risks is one of the key priorities of the national regulatory authorities, as these risks are often associated to the elements of corruption. The European regulatory framework encompasses a series of important legal instruments to fight against corruption beginning with the year 1995, prior to entering into force of the Joint Action on corruption in the private sector.

However, there is not yet any mechanism to monitor the existence and to evaluate the effectiveness of anti-corruption policies at Member States and EU levels, in a coherent and cross-sectional approach. The main international mechanisms aimed to monitor and assess the corruption are the following: the United Nations Convention against corruption (UNCAC), the OCED Bribery Working Group, and the Group of States against corruption (GRECO).

The OCED working group on bribery in international business transactions focuses on the specific issue of bribery with regards to foreign officials engaged in international commercial transactions [15] and cannot be extended to other areas of importance for the fighting against corruption in the EU.

The United Nations Convention against corruption (UNCAC) started its activity in December 2005 and the EU joined the initiative in September 2008. The Conference of Member States to UNCAC adopted the mandate of the review mechanism for the implementation of UNCAC in November 2009.

However, as long as the UNCAC review mechanism is, in fact an intergovernmental instrument, this is a feature likely to limit its potential to address corruption-related issues at 
EU level, as the cross-review system may not address the policy areas of particular relevance for the EU. Besides, some of the Member States of the initiative could have anticorruption standards lower than the rest of the EU member states.

\section{Statistics, researches, and measurements used in assessment of the integrity risks}

According to the Corruption Perceptions Index in 2019 [16], the top of the countries perceived as least corrupt are the following: Denmark and New Zealand with a score of 87 points out of 100 possible, Finland (86 points), followed by Singapore, Sweden, and Switzerland ( 85 points). The ranking is done by assignment of points from zero to 100 , in which 0 means "very corrupt" and 100 means "not corrupted at all", respectively. For every country, there are used a different number of sources, which may vary from three to sixteen; the employed methodology is supervised by Transparency International in order to ensure the meeting of the appropriate quality standards. The region with the highest average is Western Europe and the European Union (66 points), whilst at the opposite pole SubSaharian Africa is placed. For a score of 44 points, Romania is placed the $70^{\text {th }}$ out of 180 countries, 9 positions lower than in 2018. The deterioration in the quality of the Romanian business environment is reflected also by the diminution of the score in absolute value, from 48 points in 2017 and 47 points in 2018, and thereby reaching the value from 2012 . The performance in 2019 is equal to that of the Hungary, whilst Greece with 48 points is ranked the $60^{\text {th }}$, and Bulgaria (43 points) is placed the $74^{\text {th }}$. The performance of Western Europe and the European Union of 66 points is unchanged since 2017 [16-17].

However, beginning with 2017, the top countries of the hierarchy gather scores under 90 points, which may be considered as an overall trend of falling scores in the leader board. In this context, the evolution in Romania may be considered as an alignment to slight downward trend. In order to improve the situation, particularly in Romania, the authors consider that, besides the means of coercion, there is necessary a systematic approach to limit the corruption, by empowering the decision makers and fostering the involvement of local communities.

The possible solution resides in implementation of certain proposals, for the attention of both the business environment, and the central and local public administration [18]:

- the improvement and updating of the applicable standards in the field of local governance, through implementing the integrity system within the local administration. A functional system of this type can play an important role in fostering the integrity and, thereby in preventing of corruption. Such a project has to be assumed by every person involved in the development of the local communities, starting from the mayors and local councilors, to businessmen, NGOs and ordinary citizens;

- developing and fostering the ethics and compliance management systems within the organizations, through the identification and implementing of the ethics and ethical values necessary to ensure the effective organizational functioning, good governance and increase the stakeholders' trust with regards to the specific brand.

Consequently, appears necessary to foster the role of prevention within the public administration, through the implementation of transparent and reliable mechanisms, aimed to limit the integrity vulnerabilities, for the efficient expenditure of the public funds, in order to improve the level of integrity in public institutions as a whole. As the economic sector plays a key role in shaping of the societal response to corruption, considering that an integrated and transparent business environment can decisively contribute to economic development of every country, in our opinion, there are necessary meliorations in compliance and integrity mechanisms within the private sector, as a prerequisite for the economic competitiveness. 
It is widely considered that there is a strong relationship between the quality of the business environment and the economic freedom. Thereby, in the Economic Freedom Index 2020, developed by the Heritage Foundation, Romania is placed on the 38th place in the world, out of a total of 178 evaluated countries, for a score of 69.7 (out of 100), corresponding to a level considered "moderately free"; this score is just under 70, from which the economy is considered "mostly free". The latest index reveals that in Romania it is more difficult to develop a business than in countries like Cyprus, Bulgaria, Armenia or Rwanda, but easier than in Kazakhstan, Botswana, Poland, Belgium or Portugal. The evolution is positive, in both relative terms compared to the $61^{\text {st }}$ place occupied in 2016, and both the score, compared to 65.6 points in 2016 [19-20].

In addition, regarding the quality of the economic environment, the findings of the European barometer of 2019 on the perception of corruption, at the question "How widespread is the corruption (in our country)" the perception reported a ratio of $83 \%(80 \%$ in the previous report in 2017), whilst the European average is $71 \%$ (68\% in 2017) [21-22]. From this perspective, the most widespread perception is in Croatia, Cyprus, Greece, Spain and Portugal, for ratios over $94 \%$. However, $64 \%$ of the pooled Romanians declared that they consider as the corruption affects their daily life. This is the highest national reported level, with this respect, followed by Cypriotes, Portuguese, Spaniards and Greeks. The corresponding values are presented in the fig. 1 .

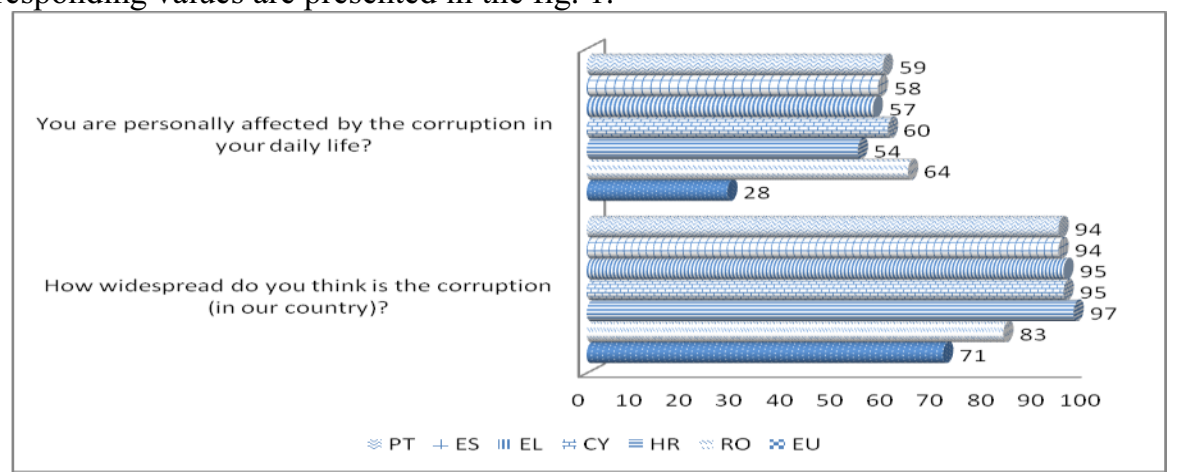

Fig. 1. Source: Authors, based on [21].

According to the aforementioned research, for a considerable majority of Europeans, the corruption is unacceptable $(69 \%)$, tolerated $(27 \%)$ or even acceptable $(4 \%)$, whilst the analogous ratios in case of Romanians are $49 \%, 38 \%$, and $13 \%$ respectively. It is noticeable that this represents the highest ratio of the opinion according to that the corruption is acceptable amongst the other European member states, followed by Austria (9\%) and Hungary (8\%). (fig. 2.)

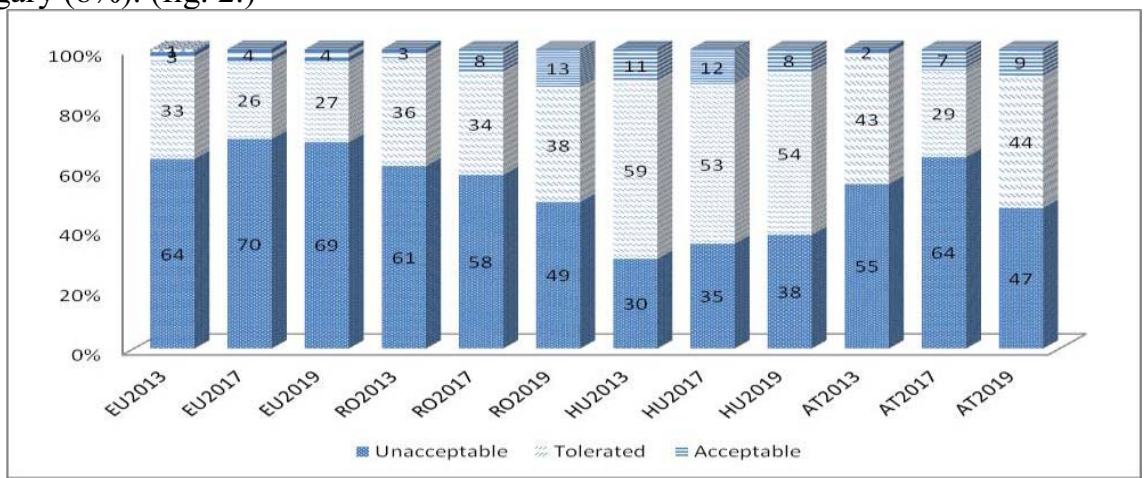

Fig. 2. Tolerance index to corruption. Source: Authors, based on [21-23]. 
With regards the forms of corruption, from the same barometer there might be observed that the Europeans consider as "always acceptable":

- Doing a favour: 4\% European average, with the highest levels in Romania, Slovakia and Austria (8\%), and the lowest in Denmark and in Portugal (2\%). Nevertheless, summing up the values of the ratios in population which consider also acceptable this type of conduct results the following figures: $59 \%$ in Hungary, $53 \%$ in Slovakia, and, respectively, 26\% in Austria and Romania (2017). Considering the similar approach, with respect to the year 2019, the figures are the following: 55\% in Hungary, 39\% in Slovakia and Austria, and respectively, $37 \%$ in Romania. The comparative situation of the considered researches is presented in fig. 3 .

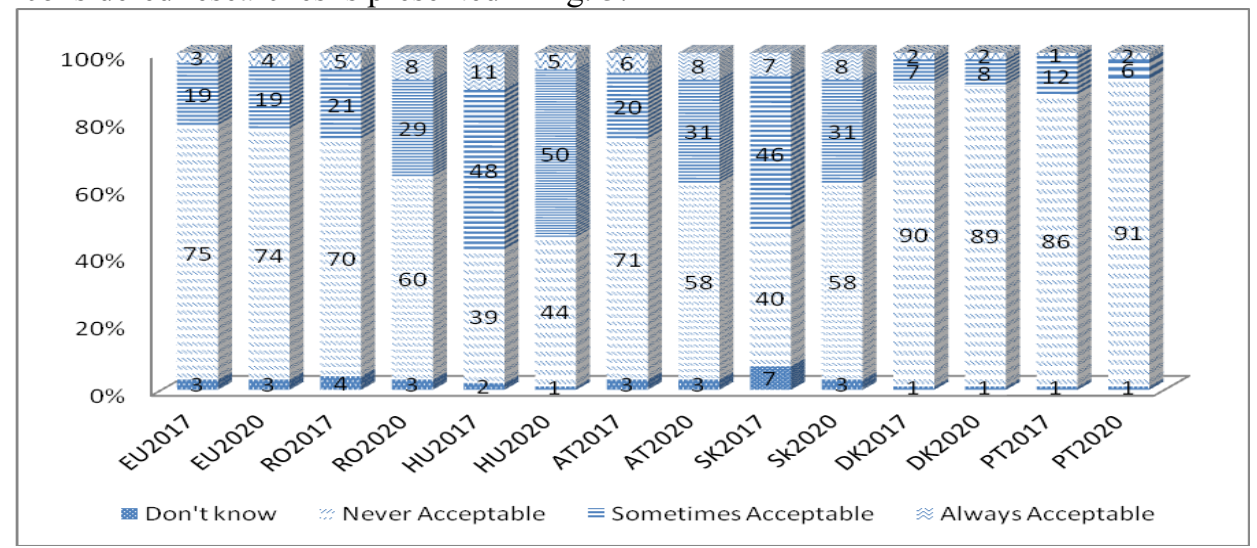

Fig. 3. The average ratios of respondents in EU and in several EU member states which indicated the tolerance levels of doing a favour to get something from a public administration or a public service. Source: Authors, based on [21-22].

- Giving a gift: $3 \%$ European average, with the highest ratios in Romania (11\%), followed by Austria (10\%) and Hungary (8\%). As in the situation previously presented, considering the ratios in population which consider also as "acceptable", and summing up the values, results the following: $60 \%$ in Latvia and in Hungary; $50 \%$ in Croatia; $46 \%$ in Czech Republic; and 36\% in Romania (2017). The findings for the corresponding evolutions in the year 2019 are: $57 \%$ in Latvia; $56 \%$ in Hungary, $50 \%$ in Croatia; $50 \%$ in Czech Republic; and 45\% in Romania. The fig. 3 presents the situation, based on the data acquired during from the researches conducted in 2017 and in 2019.

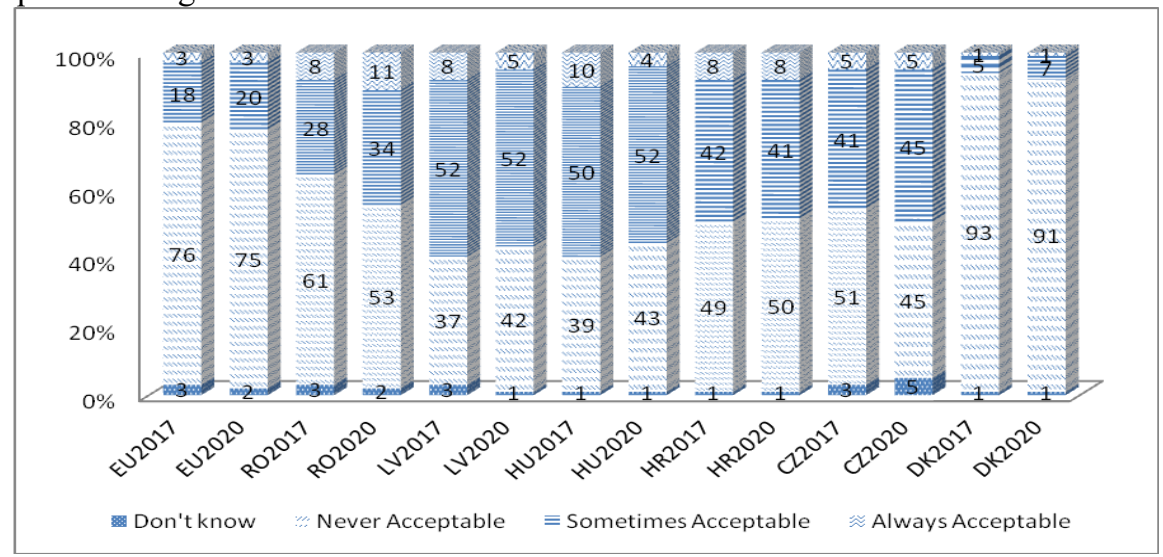

Fig. 4. The average ratios of respondents in EU and in several EU member states which indicated the tolerance levels of giving a gift to get something from a public administration or a public service. Source: Authors, based on European Commission [21-22]. 
- Giving money: 2\% European average, reporting the highest levels in Romania (12\%), followed by Austria and Hungary (both with 5\%). The data in the graph depict a slight increase in ratio $(+2 \%)$ of the Europeans which consider that is acceptable to give money to get something from a public administration or a public service. Following the approach in the previously presented situations, and summing up the ratios in population which consider also as "acceptable" this type of conduct, the results are the following: $43 \%$ in Hungary, 29\% in Latvia, and, respectively, 26\% in Austria and Romania (2017). Considering the similar approach, with respect to the year 2019, results: $43 \%$ in Hungary; $37 \%$ in Romania, $28 \%$ in Austria; and, $25 \%$ in Latvia, respectively. The comparative situation of the considered researches in 2017 and in 2020 is presented in fig. 5.

Considering the issue of integrity risks from the three perspectives above presented, there may be noticed that in three countries, namely in Hungary, Austria and Romania continue to share a perception that may be considered as common in general terms. However, the perception of the Romanians is placed against the downsizing trend in the European Union with respect of acceptability of offering money. In addition, although in Austria and Hungary the perception of acceptability of doing favours or offering gifts continue to be situated above the levels specific to Romania, the tolerance of offering money is downsizing, specifically in Austria reporting far more reduced levels.

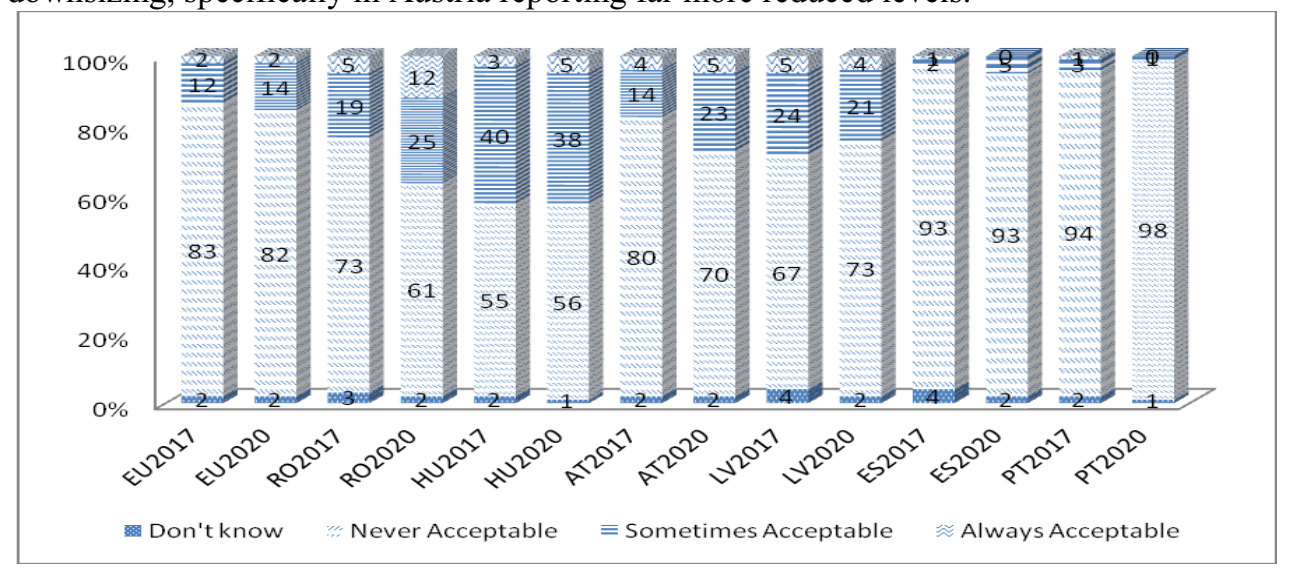

Fig. 5. The average ratios of respondents in EU and in several EU member states which indicated the tolerance levels of giving money to get something from a public administration or a public service. Source: Authors, based on European Commission [21-22].

An interesting evolution regards the way of Romanian citizens are reporting themselves to the phenomenon of corruption. Thereby, in 2013 Eurobarometer, there has been remarked the relatively high ratio of respondents in expressing a point of view, with regards of all the three evaluated dimensions (offering favours, gifts or money) (European Commission, 2014). More specifically, about one tenth in pooled Romanians (11\%), Bulgarians $(10 \%)$ and Latvians (8\%) declared themselves unable to express an opinion in this respect, compared with the European average of $2 \%$; nevertheless, in the latest survey (2019), the weight of non-responses dropped to $3 \%$ (equal to the European average).

Analogous, the relatively high ratio of non-responses reported in 2013 in Romania (8\%, unlike any other EU country) with respect to the availability to offer a gift in exchange of getting something from a public authority has been also abandoned in the 2019 survey. Thereby, the rate of non-responses to this item is of $2 \%$, consistent to the European average.

With regards of offering money, the above findings are also maintaining. Thus, the weight of non-responses to this item in Romania is of $2 \%$, similar to the European average, in comparison to 2013, when the non-responses weighted for almost one-tenth, that is, $9 \%$ 
(2\% European average). It is also noticeable that in Denmark, perceived as one of the most integer countries in Europe, in 2013, 25\% of the interviewees reported their availability to offer money in exchange of a public service [23]. On the other hand, in the survey deployed in 2019 the highest levels of non-responses concerning this matter were reported in United Kingdom and Malta (6\%), Bulgaria and Luxembourg (4\%).

Interestingly, the opinion that it is acceptable to give money in exchange from a public administration or a public service has gained ground in $13 \mathrm{EU}$ Member States in comparison with the previous survey (conducted in 2017), particularly in Romania (37\%, with an increase of $13 \mathrm{pp}$ ), followed by Austria (28\%,+10 pp). [20-21]. As well, from the reported opinions in the survey conducted, results that Romania is the only EU member state where over a tenth of respondents consider as ,always acceptable" to give money in exchange from a public administration or a public service [20].

However, the perceived corruption measurements present some lacks, which represent a permanent source for their criticism:

- their implicit definition, based on the surveys, which are further on employed for the subsequent construction of the measurements. This is the case of the above-mentioned CPI [24-25];

- the changes in the evaluation of governance might occur following the observation of some errors in the past [26]. However, the post-factum analysis represents a general feature of economic policy measurements, largely addressed in the literature [27-29];

- another specific of the statistic measurements is their limited possibilities for action [28-29]. The integrity measurements also inherit this feature [30].

The Index of Public Integrity (IPI) is a measure jointly-elaborated by the European Research Center for Anti-corruption and State-building (ERCAS) and Hertie School of governance. The IPI is based on six actionable elements, which reflect the balance of measures that can contribute to effective control of corruption: administrative burden, judicial independence, trade openness, e-citizenship, budget transparency, and freedom of the press [31]. Based on previous researches, the IPI represent a valuable measure, which tries to mitigate the weaknesses of the existing corruption perception measures [32]. According to the last three rankings within IPI, the positions for Romania are the following: - $\quad$ in 2015 , the $32^{\text {nd }}$ of 109 world countries, and the $23^{\text {rd }}$ in the EU, for a score of 7.58 ;

- $\quad$ in 2017 , the $31^{\text {st }}$ of 109 world countries, and the $22^{\text {nd }}$ in the EU, for a score of 7.73 ;

- $\quad$ in 2019 , the $33^{\text {rd }}$ of 117 world countries, and the $20^{\text {th }}$ in the EU, for a score of 7.69 .

Although, there was a slight backward step in 2019, it is noticeable the improvement in the score afferent to year 2017, which followed the progresses in administrative simplification and digitization of public services processes, moving ahead of other countries in the region, like Hungary, Greece, Croatia, Bulgaria, and Poland.

\section{Conclusions}

Overall, there may be noticed a slight diminution in the citizens' vigilance towards unfair practices, aiming to get something from a public administration or a public service, and this type of conduct seems to be more spread in the south-eastern and central countries; amongst them, Latvia represents an unexpected apparition.

Nevertheless, amongst the above corruption examined practices in Europe, in case of Romania there has to be pointed out a negative evolution regarding giving money in exchange of getting something from a public administration or a public service. This development is as worse as it is evolve amid the increase of European public awareness regarding the dishonest character of this particular type of conduct, and in obvious contradiction with the European trend. Thereby, 7\% more in those pooled in Romania indicated the practice as one that has gained ground. This evolution is far followed in 
Hungary, where, nevertheless, the change of $2 \%$ (from $3 \%$ to $5 \%$ ) represents rather a qualitative option from those which, during the previous survey indicate the practice just as "acceptable" (from $40 \%$ to $38 \%$ ). Interestingly, the Iberic countries reached a "zero tolerance" in the level of this type of corruption.

However, the findings of the Eurobarometer, as well as other survey-researches, are predominantly based on the public perception and less on the concrete experiences. Consequently, building of adequate indicators and their validation through the statistic methods, as well as and their further employment in research and as basics for policy measurements, represent a useful demarche in efforts of increasing the public integrity, as prerequisites for a healthy economic growth and the fair distribution of wealth.

\section{References}

1. SOED (2007). The New Shorter Oxford English Dictionary, Sixth Edition. London: Oxford University Press.

2. Ardelean, A. (2014). Spre o ierarhizare a principiilor fundamentale de etică: Integritatea ca principiu central. Audit Financiar, 12 (120) 3-19.

3. Coman-Kund, L. (2007). Deontologia şi statutul funcţionarilor din administraţia publică. Galaţi: Editura Europolus.

4. Milutin, I. M. (2009). Etica şi integritatea în managementul public. Studia Universitatis Vasile Goldiş, Arad-Seria Ştiinţe Economice, 19(1), 528-541.

5. Postelnicu, R. P., Dimitriu, M. N. (2003). Adoptarea unui Cod de Conduita pentru Funcţionarii Publici - Prioritate pentru România, Revista de Drept Public 3.

6. Lucaites, J. L.; Condit, C. M., \& Caudill, S. (Eds). (1999). Contemporary rhetorical theory: A reader. London: Guilford Press.

7. Karthikeyan, C. (2017). A meta analytical study on leadership integrity: a leadership ethics perspective. International Journal of Management, IT \& Engineering, 7(4), 240263.

8. OECD, (2010), Good Practice Guidance on Internal Controls, Ethics, and Compliance. https://www.oecd.org/daf/anti-bribery/44884389.pdf.

9. European Parliament (2012). Working document on corruption. Special committee on organised crime, corruption and money laundering

10. Council of Europe (1999). Criminal Law Convention on Corruption. Strasbourg: European Treaty Series - No. 173.

11. Ashforth, B. E., Gioia, D. A., Robinson, S. L., Trevino, L. K. (2008). Re-viewing organizational corruption. Academy of Management review, 33(3), 670-684.

12. Cuervo-Cazurra, A. (2016). Corruption in international business. Journal of World Business, 51(1), 35-49.

13. The Council of the European Union (2003). Council Framework Decision 2003/568/JHA on combating corruption in the private sector, Official Journal of the European Union, 31.07.2003, L192 54 - 56.

14. Lee, J. H. (2006). Business corruption, public sector corruption, and growth rate: time series analysis using Korean data. Applied Economics Letters, 13(13), 881-885.

15. OECD (2014). Country monitoring of the OECD Anti-Bribery Convention. http://www.oecd.org/document/12/0,3343, en $2649 \quad 34859 \quad 35692940 \quad 1 \quad 1 \quad 11,00 . h t m l$

16. Transparency International (2020), Corruption Perceptions Index in 2019. Berlin: GTransparency International.

17. Transparency International (2019), Corruption Perceptions Index in 2018. Berlin: Transparency International.

18. Transparency International Romania (2018). Corruption Perceptions Index in Romania 2017. https://www.transparency.org.ro/politici si studii/indici/ipc/2017/CPTIROro.pdf 
19. Miller, T, \& Kim, AB (2016), Index of Economic Freedom - Promoting Economic Opportunity and Prosperity, institute for economic freedom and opportunity / The WSJ. The Heritage Foundation and Dow Jones \& Company, Inc.

20. Miller, T; Kim, AB; Roberts JM \& Tyrrell P (2020). 2020 Index of Economic Freedom. The Heritage Foundation: Washington, DC

21. European Commission (2020). Special Eurobarometer 502 - Corruption Report. European Union. doi:10.2837/91891.

22. European Commission (2017). Special Eurobarometer 470 - Corruption Report. European Union. doi:10.2837/513267.

23. European Commission (2014). Special Eurobarometer 397 - Corruption Report. European Union.

24. Voigt, S. (2009). How (not) to Measure Institutions. Joint discussion paper series in economics, No. 2009, 37.

25. Knack, S. (2006). Measuring Corruption in Eastern Europe and Central Asia: A Critique of the Cross-Country Indicators. World Bank Policy Research Department Working Paper 3968.

26. Hawken, A. \& Munck G.L. (2011). Does the evaluator make a difference? Measurement validity in corruption research. IPSA Committee on Concepts and Methods Working Paper Series Nr. 48.

27. Lucas, Robert (1972). Expectations and the Neutrality of Money. Journal of Economic Theory. 4 (2): 103-24.

28. Sims, C. (1972). Money, Income, and Causality. American Economic Review 62: 4 (September): 540-552.

29. Sargent, Th. J. \& Wallace, N. (1975). 'Rational' Expectations, the Optimal Monetary Instrument, and the Optimal Money Supply Rule. The Journal of Political Economy Vol. 83, No. 2, pp. 241-254.

30. Galtung (2006). "Measuring the Immeasurable: Boundaries and Functions of (Macro) Corruption Indices." In Sampford, C. J., Shacklock, A. H., Connors, C., \& Galtung, F. (eds.). Measuring corruption. Ashgate.

31. Index of Public Integrity webpage https://integrity-index.org/about/.

32. Mungiu-Pippidi, A. \& Dadašov, R. (July 2016). Measuring Control of Corruption by a New Index of Public Integrity. European Journal on Criminal Policy and Research 22, 415-438. https://doi.org/10.1007/s10610-016-9324-z. 